107TH CONGRESS

1ST SESSION

S. RES. 3

To elect Robert C. Byrd, a Senator from the State of West Virginia, to be President pro tempore of the Senate of the United States, and to elect Strom Thurmond, a Senator from the State of South Carolina, to be President pro tempore of the Senate of the United States.

\title{
IN THE SENATE OF THE UNITED STATES
}

JANUARY 3, 2001

Mr. Daschle (for himself and Mr. LOTT) submitted the following resolution; which was considered and agreed to

\section{RESOLUTION}

To elect Robert C. Byrd, a Senator from the State of West Virginia, to be President pro tempore of the Senate of the United States, and to elect Strom Thurmond, a Senator from the State of South Carolina, to be President pro tempore of the Senate of the United States.

1 Resolved, That Robert C. Byrd, a Senator from the

2 State of West Virginia, be, and he is hereby, elected Presi-

3 dent of the Senate pro tempore, to hold office until 12:00

4 meridian on January 20, 2001, in accordance with rule

5 I, paragraph 1, of the Standing Rules of the Senate.

6 SEc. 2. That Strom Thurmond, a Senator from the

7 State of South Carolina, be, and he is hereby, elected 
1 President of the Senate pro tempore, to hold office effec2 tive 12:00 meridian on January 20, 2001, in accordance 3 with rule I, paragraph 1, of the Standing Rules of the 4 Senate. 